\title{
The Use of Wood Chips for Revitalization of Degraded Forest Soil on Young Scots Pine Plantation
}

\author{
Andrzej Klimek ${ }^{1}$, Stanisław Rolbiecki ${ }^{2}$, Roman Rolbiecki ${ }^{2}$, Grzegorz Gackowski ${ }^{3}$, \\ Piotr Stachowski ${ }^{4}$ and Barbara Jagosz ${ }^{5, * \text { (D) }}$ \\ 1 Department of Biology and Animal Environment, University of Science and Technology, Mazowiecka 28, \\ 85-084 Bydgoszcz, Poland; klimek@utp.edu.pl \\ 2 Department of Agrometeorology, Plant Irrigation and Horticulture, University of Science and Technology, \\ Bernardyńska 6, 85-029 Bydgoszcz, Poland; rolbs@utp.edu.pl (S.R.); rolbr@utp.edu.pl (R.R.) \\ 3 Department of Biology and Animal Environment, University of Science and Technology, Kordeckiego 20, \\ 85-225 Bydgoszcz, Poland; Grzegorz.Gackowski@utp.edu.pl \\ 4 Institute of Land Improvement, Environmental Development and Geodesy, \\ Poznan University of Life Sciences, Piątkowska 94, 60-649 Poznan, Poland; pstach@up.poznan.pl \\ 5 Department of Plant Biology and Biotechnology, University of Agriculture in Krakow, Mickiewicza 21, \\ 31-120 Krakow, Poland \\ * Correspondence: Barbara.Jagosz@urk.edu.pl; Tel.: +48-12-662-5186
}

Received: 28 May 2020; Accepted: 14 June 2020; Published: 17 June 2020

\begin{abstract}
The aim of the study was to assess the impact of several methods of mulching degraded forest soil with wood chips on the development of mite (Acari) community, with particular emphasis to oribatid mites (Oribatida), and on the growth of young plantings of Scots pine (Pinus sylvestris L.). Mulching with wood chips should contribute to revitalize soil fauna and restore natural forests on degraded soils. Scots pine seedlings were planted at the post-military training ground. Four experimental treatments were tested: control—uncovered soil (C), mulching with wood chips (W), $W+$ mycorrhiza preparation (WM), and W + forest litter (WL). At the end of the growing season in 2012, 2013 and 2014, the following plant measurements were carried out: length of annual increment of the main stem, stem base diameter, number and lengths of lateral shoots in the annual whorl. The mite calculations included average mite density, dominance index, species richness, oribatid mite diversity, average number of species, and Shannon general species diversity index. The use of mulching with wood chips did not significantly affect the growth characteristics of Scots pine plants, but strongly increased the mite community. After mulching, the total number and species diversity of Acari increased many times, and Oribatida began to dominate among micro-arthropods. The number of Oribatida increased most in W. The largest species diversity was observed in WL. 24 species of Oribatida were found that were used as the bio-indicators of soil succession changes. Tectocepheus velatus clearly dominated in all mulching treatments. Oppiella nova and Scutovertex sculptus were also numerous populations of Oribatida. The study shows that mulching with Scots pine wood chips, especially with the addition of forest litter, significantly enriches soil fauna and is therefore useful in the regeneration process of degenerated forest soils.
\end{abstract}

Keywords: Acari; forest litter; mite; mulching; mycorrhiza preparation; oribatid mite; Oribatida; Pinus sylvestris $\mathrm{L}$.

\section{Introduction}

According to the data of the Central Statistical Office [1], devastated and degraded land in Poland requiring reclamation and development occupies approximately 64 thousand hectares. There are many reasons for the devastation and degradation of land in Poland, mainly industrial or military activities. 
The size of this area has changed only slightly in recent years. Since 2005, only an area of between 1222 and 1861 hectares per year has been reclaimed, of which only 581 to 1132 hectares have been restored to plantations.

The best way to revitalize degraded areas is to restore the forest biocenosis, which is the most natural and biodiverse land biocenosis in our climate zone [2]. Nowadays, in Poland, as a result of the implementation of the reforestation program for rural areas, forest resources are constantly growing. These areas usually have poor soil, so they are most often reforested by Scots pine, which is currently the dominant forest-forming species, covering in 2017 as much as $58.2 \%$ of the forest area in our country [3]. Scots pine can grow in a wide range of environmental condition and tolerates even poor soils: "sandy, loamy, and soil containing shale and granite". It also occurs in peat bogs, can grow on soils with a pH of 4 to 7 , and in addition, it is resistant to frost and dries well. In the past, planting Scots pine in the climate zone in which Poland is located was not scientifically justified [2]. Today, due to the dynamically changing climatic conditions, it is recommended to plant Scots pine in our country [3]. According to one of the possible emission scenarios described at the end of the 21st century, the global temperature will increase by about $4{ }^{\circ} \mathrm{C}$. In Poland, as expected, the temperature will rise in the range of from 2 to $4{ }^{\circ} \mathrm{C}$, during when no increase in precipitation is expected [4]. An increase in air temperature without changing the amount of precipitation can lead to excessive drying of the soil, which will cause additional difficulties in the revitalization process and reforestation of degraded land.

Degraded soils are usually devoid of a humus layer, which protects the soil from drying out and creates a favorable environment for the development of soil microflora and microfauna. The lack of an organic matter layer on the soil surface also delays the process of natural succession and has a negative impact, mainly in the warm and dry summer months, on the population of soil mesofauna, such as mites (Acari) [5]. Most mites are sarcophagi, for example, oribatid mites (Oribatida), but some mites are parasites (mainly ectoparasites) or predators. Sarcophagi mites participate in the decomposition of organic matter, which in turn affects plant growth. The forest soil is inhabited by a large number of mites, especially the oribatid mites, which constitute from about $60 \%$ to $90 \%$ of all Acari. Oribatid mites, by crushing organic matter, support bacteria and fungi in releasing nutrients necessary for plant growth [6].

As the indicators of soil biological activity, enzymatic and respiratory activity, microbial biomass, species diversity and abundance of microorganisms are most often proposed [7,8]. Only sporadically, when determining the biological state of soils, the species diversity and abundance of fauna are considered, although it is the part of the edaphon, which, especially in forest soils, performs very important functions for the entire ecosystem. Oribatid mites are considered by many authors to be good bio-indicators of the state of the environment [6,9-13]. Many research results indicate that oribatid mites can be vectors or stimulators of the development of many microorganisms, including fungi, which form mycorrhiza systems, so desirable in the environment [14-19]. To compare the stability (balance) of ecosystems, acarologists often use the abundance ratio of two orders of mites: Oribatida to Actinedida (Or/Ac) [6]. According to Werner and Dindal [20] the Oribatida to Actinedida ratio below 1.0 is recorded on arable land, while above 1.0 is typical for more stable ecosystems, e.g., semi-natural meadows and forests, i.e., on soils with a significant share of organic matter.

The growth and development of tree seedlings can be significantly influenced by ectomycorrhizal fungi, which play an important role in biogeochemical cycles and are involved in the nutrition of host plants. The disappearance of ectomycorrhiza fungi is associated with mechanical soil cultivation, excessive fertilization and alkalization of the soil, and the use of pesticides. Areas degraded by military activities may also be deprived of ectomycorrhiza inoculum. Therefore, the enrichment of degraded soils with edaphon from forest soil seems to be a good solution [21-24].

A number of studies confirm the usefulness of wood chips, especially Scots pine wood chips, as mulching material, which creates good conditions for the development of soil mesofauna. In the first stage of seedling growth (forest succession), mulching with wood chips can replace the layer of 
forest litter, which naturally occurs on the forest soil of renovated forests after cutting down the mature trees [25-28].

The phenomenon of increasing the number of oribatid mites by adding organic matter to degraded soil, as well as the beneficial effect of soil mites on the development of plants, especially trees, is well known. The purpose of current research was to determine the most effective mulching method to revitalize soil fauna and restore natural forests in a degraded forest area. Our research hypothesis assumed that the use of mulch with wood chips with the addition of mycorrhiza preparation or forest litter will increase the biological activity of soil and improve the growth of young Scots pine trees. To verify the assumed research hypothesis, the following specific objectives were formulated: (1) the use of different modifications of Scots pine wood chips as a substitute for the humus layer will affect the development of indicators of soil biological activity, such as mites (Acari), but especially oribatid mites (Oribatida); (2) the use of different methods of mulching with Scots pine wood chips will affect the selected growth parameters of Scots pine plants.

\section{Materials and Methods}

\subsection{Description of Experiment}

The research was carried out at the post-military training ground in Bydgoszcz-Jachcice, which is currently managed by the Żołędowo Forest District (Forestry Jagodowo, branch 222c, GPS: 53.156943 N, $17.986440 \mathrm{E})$. Before renewal, the area was a former agricultural field with a rare and degraded stand of Scots pine, which burned down in 2010. According to the Tree Stand Data Sheet of the Żołedowo Forest District, the soil on this area was of the type of rusty soils and a subtype of rusty algae soils. Before planting, the soil surface was cultivated with a double-layer forest plow. For planting, two-years-old Scots pine (Pinus sylvestris L.) seedlings with a covered root system, from the Bielawa container nursery (Forest District Dobrzejewice), were used. Scots pine seedlings were planted in spring 2011. After reforestation, this habitat was classified as "fresh boron", dominated by Scots pine with the addition of $10 \%$ silver birch (Betula pendula Roth).

The factor investigated in the experiment was soil mulching using Scots pine wood chips, applied in the following treatments: (1) uncovered soil (without mulching, but covered with moss and individual clumps of grass, mainly Corynephorus canescens L.) as a control (C), (2) soil mulched with wood chips (W), (3) soil mulched with wood chips with the addition of mycorrhiza preparation (WM), (4) soil mulched with wood chips with the addition of forest litter (WL). Three replicates of the microplots arrangement were applied. There were four micropots in each replicate (one for each treatment). Each microplot was $5 \mathrm{~m}$ long and covered three rows of Scots pine plants. The distance between the rows was $1.5 \mathrm{~m}$, and between the plants in a row of $0.8 \mathrm{~m}$. One microplot contained 18 plants (six in each row); eventually, 56 plants were evaluated in all three replicates for each treatment. Mulching with wood chips was carried out on 12 April 2012. Wood chips were prepared from scrub Scots pine trees cut at the post-military training ground. The wood was shredded with a BRUKS 805 disk-chipper. The wood chips were thin squares with a side length of $5 \mathrm{~mm}$ and a thickness of $1 \mathrm{~mm}$. On 25 October 2012, wood chips on WM microplots were inoculated with mycorrhiza biopreparation (2.5\% biopreparation with the mycelium of Hebeloma crustuliniforme (Bull.) Quél.). At the same time, a $10 \%$ addition of fresh forest litter from mature fresh coniferous forest in the Białe Błota Forestry was applied on WL microplots.

\subsection{Scots Pine Growth Measurement}

At the end of 2012, 2013 and 2014, after the end of the growing season, a number of developmental characteristics of young Scots pine trees were measured. The measurement was carried out: length of annual increment of the main stem $(\mathrm{cm})$, stem base diameter $(\mathrm{mm})$, number $(\mathrm{pcs})$ and sum of the lengths $(\mathrm{cm})$ of lateral shoots in the annual whorl. 


\subsection{Acarological Research}

Samples for acarological tests were taken four times: 25 June 2013, 15 October 2013, 3 June 2014 and 21 October 2014. From each experiment treatment, at each sampling-time, 10 samples of substrate were collected (three or four samples from each microplot). In total, 40 samples with a volume of $50 \mathrm{~cm}^{3}$ each were taken from each treatment. Mite extraction was carried out for 7 days using Tullgren funnels. Then, the mites were preserved in 70\% ethyl alcohol. All mites have been identified by order and oribatid mites by species or genus. Adults and juveniles were counted together. In total, 6499 mites (Acari) were identified, including 5104 oribatid mites (Oribatida).

The average density $(N)$ of the mites was measured in $50 \mathrm{~cm}^{3}$ of substrate. The domination index (D) was estimated in \%. Species richness and diversity of oribatid mites was determined on the basis of the number of species $(S)$. The average number of species in the sample $(s)$ and the Shannon general species diversity index $\left(H^{\prime}\right)$ were also calculated.

\subsection{Statistical Analysis}

Before statistical analysis, the measurement results were subjected to logarithmic transformation - $\ln (x+1)$ according to Berthet and Gerard [29]. Statistical analysis was performed using the Statistica 13.3 software package. The Kolmogorov-Smirnov test was used to assess the compliance of the distribution of measurable parameters with the normal distribution. However, due to the lack of normal distribution a non-parametric analysis of variance (Kruskal-Wallis $H$ test) was performed. For statistically significant differences $(p<0.05)$, an analysis was performed for each pair (Mann-Whitney $U$ test) to select the significantly different means. The growth characteristics of Scots pine as well as mite calculations are presented as the average of three years of research.

\section{Results}

\subsection{Scots Pine Growth Characteristics}

The use of mulching treatments did not significantly affect most the growth characteristics of Scots pine plants in the first three years after planting (Table 1). There were no significant differences in the average length of annual increment of the main stem between the studied treatments. The average value of this feature was $17.1 \mathrm{~cm}$. The lowest length of annual increment of the main stem $(14.0 \mathrm{~cm})$ was noted on soil mulched with wood chips with the addition of forest litter and the highest $(18.7 \mathrm{~cm})$ on soil mulched only with wood chips. The average stem base diameter of Scots pine was the only studied growth feature in which statistical differences were found. The average stem base diameter on plots mulched with wood chips $(13.6 \mathrm{~mm})$ was much lower than on control plots $(17.4 \mathrm{~mm})$. However, there were no important differences in stem base diameter between control and other mulching treatments. Both the number and the sum of the lengths of lateral shoots in the annual whorl did not differ significantly between the tested treatments. The highest values of observed traits were recorded in the case of control plants $(6.2$ pcs and $124.1 \mathrm{~cm}$, respectively), while the lowest were recorded on plots mulched with wood chips with the addition of forest litter $(4.8$ pcs and $95.4 \mathrm{~cm}$, respectively) and on plots mulched only with wood chips $(95.4 \mathrm{~cm})$. The average sum of the lengths of lateral shoots in the annual whorl was 5.6 pcs and $107.7 \mathrm{~cm}$, respectively. 
Table 1. Growth characteristics of young Scots pine trees (presented as the average of three years of research).

\begin{tabular}{ccccc}
\hline Treatment & $\begin{array}{c}\text { Length of Annual } \\
\text { Increment of the } \\
\text { Main Stem } \mathbf{( c m )}\end{array}$ & $\begin{array}{c}\text { Stem Base } \\
\text { Diameter (mm) }\end{array}$ & $\begin{array}{c}\text { Number of Lateral } \\
\text { Shoots in the Annual } \\
\text { Whorl (pcs) }\end{array}$ & $\begin{array}{c}\text { Sum of Lengths of } \\
\text { Lateral Shoots in the } \\
\text { Annual Whorl (cm) }\end{array}$ \\
\hline C & 17.8 & 17.4 & 6.2 & 124.1 \\
W & 18.7 & 13.6 & 5.4 & 95.4 \\
WM & 17.8 & 15.5 & 5.9 & 115.9 \\
WL & 14.0 & 14.8 & 4.8 & 95.4 \\
Mean & 17.1 & 15.3 & 5.6 & 107.7 \\
LSD $_{0.05}$ & ns & 2.835 & $\mathrm{~ns}$ & $\mathrm{~ns}$ \\
\hline
\end{tabular}

$\mathrm{C}=$ control (without mulching); $\mathrm{W}=$ soil mulched with wood chips; $\mathrm{WM}=$ soil mulched with wood chips with the addition of mycorrhiza preparation; $\mathrm{WL}=$ soil mulched with wood chips with the addition of forest litter; LSD = least significant difference (Mann-Whitney $U$ test) at $p<0.05 ; \mathrm{ns}=$ not significant at $p<0.05$.

\subsection{Acarological Research}

Measurement of the number of mites carried out on control plots showed their low density, which was 4020 individuals per $50 \mathrm{~cm}^{3}$ of substrate (Table 2, Figure 1). Actinedida (88.6\%) clearly dominated among the mites. Another large group was oribatid mites, which accounted for $9.2 \%$ of all mites. The abundance ratio of two orders of mites: Oribatida to Actinedida (Or/Ac) was extremely low (0.10). On mulched plots, the density of mites was many times higher and ranged from 29,630 to 70,760 individuals per $50 \mathrm{~cm}^{3}$ of substrate. Moreover, unlike control plots, mulched plots were dominated by oribatid mites, whose number ranged from $64.1 \%$ to $70.8 \%$ of all mites. On mulched plots, Actinedida was the second large group, and Mesostigmata was the third largest group (on WM and WL plots). The abundance ratio of two orders of mites: Oribatida to Actinedida (Or/Ac), on mulched plots, was high and varied between 2.6 and 6.94. Acaridida and Tarsonemida were the least numerous mite groups in this study.

The largest population of oribatid mites was found on plots mulched only with wood chips $\left(60,440\right.$ individuals per $50 \mathrm{~cm}^{3}$ of substrate) (Table 2). In addition, the differences in the number of oribatid mites between plots mulched only with wood chips and other mulching treatments were statistically significant. However, no important difference was recorded in the number of oribatid mites between plots mulched with wood chips with the addition of mycorrhiza preparation and plots mulched wood chips with the addition of forest litter. Compared to the control plots, the size of the Actinedida population on the mulched plots increased significantly, but the differences between individual mulching treatments were not visible. The size of the Mesostigmata population on control plots and plots mulched only with wood chips was clearly lower than on plots mulched with wood chips with the addition of mycorrhiza preparation, as well as forest litter. Acaridida and Tarsonemida mites were found only on plots mulched with wood chips with the addition of mycorrhiza preparation and on plots mulched with wood chips with the addition of forest litter.

In the current study, 24 species of oribatid mite were noted (Figure 1). Most of them (21 species) were found on plots mulched with wood chips with the addition of forest litter, and only two on the control plots. Eleven and six species of oribatid mites were observed, respectively, on plots mulched only with wood chips and plots mulched with wood chips with the addition of mycorrhiza preparation.

The analysis of the average number of species in the sample (s) showed visible differences in the abundance of mite species between control plots and plots mulched only with wood chips (Table 2). The highest value of this index $(s=3.7)$ was recorded on plots mulched with wood chips with the addition of forest litter. The lowest Shannon's species diversity index $\left(H^{\prime}\right)$ was noted on control plots $\left(H^{\prime}=0.22\right)$, and the highest value of this indicator $(H=1.52)$ was found on plots mulched with wood chips with the addition of forest litter.

In the group of oribatid mites, Tectocepheus velatus clearly dominated in all treatments of the experiment (Figure 1). The highest domination index (D) (94.6\%) estimated for this species was noted 
on control plots, and the lowest (62.1\%) was detected on plots mulched with wood chips with the addition of forest litter.

On the control plots, the number of Tectocepheus velatus was only 350 individuals per $50 \mathrm{~cm}^{3}$ (Table 2). The highest population of this species was observed in the case of mulching only with wood chips (52,480 individuals per $50 \mathrm{~cm}^{3}$ of substrate). A much lower population of Tectocepheus velatus was noted on plots mulched with wood chips with the addition of mycorrhiza preparation or forest litter. Oribatula tibialis appeared only on control plots as the second species of mites (20 individuals per $50 \mathrm{~cm}^{3}$ of substrate), as well as in soil mulched with wood chips with the addition of forest litter (56 individuals per $50 \mathrm{~cm}^{3}$ of substrate). On the plots mulched only with wood chips, the second most abundant species was Scutovertex sculptus (830-6950 individuals per $50 \mathrm{~cm}^{3}$ of substrate). Oppiella nova was also a numerous species of oribatid mites on mulched plots (360-1320 individuals per $50 \mathrm{~cm}^{3}$ of substrate). Pergalumna nervosa was detected only in soil mulched with wood chips with the addition of forest litter (1260 individuals per $50 \mathrm{~cm}^{3}$ of substrate).

Table 2. Density of mites and selected species of oribatid mites ( $N$ in thousand individuals in $50 \mathrm{~cm}^{3}$ of substrate), the Oribatida to Actinedida (Or/Ac) abundance ratio, the number of species $(S)$, the average number of species $(s)$ and the Shannon's species diversity index $(H)$ of oribatid mites in the studied mulching treatments of Scots pine.

\begin{tabular}{|c|c|c|c|c|c|c|}
\hline \multirow{2}{*}{ Index-Taxon } & \multicolumn{4}{|c|}{ Treatments } & \multicolumn{2}{|c|}{ Kruskal-Wallis Test } \\
\hline & $\mathrm{C}$ & W & WM & WL & $H$ & $p$ \\
\hline$N$-Acaridida & 0.00 & 0.00 & $0.03^{\mathrm{a}}$ & $1.53^{b}$ & 31.09 & 0.000 \\
\hline$N$-Actinedida & $3.56^{\mathrm{a}}$ & $8.71^{b}$ & $6.78^{\mathrm{b}}$ & $7.13^{b}$ & 29.53 & 0.000 \\
\hline$N$-Mesostigmata & $0.09^{a}$ & $0.09^{\mathrm{a}}$ & $1.39^{b}$ & $1.45^{\mathrm{b}}$ & 26.73 & 0.000 \\
\hline$N$-Oribatida & $0.37^{\mathrm{a}}$ & $60.44^{\mathrm{b}}$ & $27.80^{\mathrm{c}}$ & $18.99^{c}$ & 71.56 & 0.000 \\
\hline$N$-Tarsonemida & 0.00 & 0.00 & $0.57^{\mathrm{a}}$ & $0.53^{\mathrm{a}}$ & 8.69 & 0.034 \\
\hline$N$-Acari (Total) & $4.02^{\mathrm{a}}$ & $70.76^{b}$ & $36.57^{c}$ & $29.63^{c}$ & 72.28 & 0.000 \\
\hline N-Oppiella nova (Oudemans) & 0.00 & $0.36^{\mathrm{a}}$ & $1.25^{\mathrm{a}}$ & $1.32^{\mathrm{a}}$ & 12.88 & 0.005 \\
\hline $\mathrm{N}$-Oribatula tibialis (Nicolet) & 0.02 & - & - & 0.06 & - & - \\
\hline N-Pergalumna nervosa (Berlese) & - & - & - & 1.26 & - & - \\
\hline N-Scutovertex sculptus (Michael) & 0.00 & $6.95^{\mathrm{a}}$ & $2.87^{\mathrm{ab}}$ & $0.83^{b}$ & 34.90 & 0.000 \\
\hline N-Tectocepheus velatus (Michael) & $0.35^{\mathrm{a}}$ & $52.48^{b}$ & $23.45^{c}$ & $11.79^{c}$ & 66.43 & 0.000 \\
\hline Others Oribatida $(N<1.0)$ & 0.02 & 0.65 & 0.23 & 3.79 & - & - \\
\hline$N$-Or/Ac abundance ratio & 0.10 & 6.94 & 4.10 & 2.66 & - & - \\
\hline$S$-Oribatida & 2 & 11 & 6 & 21 & - & - \\
\hline$s$-Oribatida & $0.23^{\mathrm{a}}$ & $1.98^{b}$ & $1.58^{\mathrm{b}}$ & $3.70^{c}$ & 89.47 & 0.000 \\
\hline$H^{\prime}-$ Oribatida & 0.22 & 0.47 & 0.56 & 1.52 & - & - \\
\hline
\end{tabular}

$\mathrm{C}=$ control-without mulching; $\mathrm{W}=$ soil mulched with wood chips; $\mathrm{WM}=$ soil mulched with wood chips with the addition of mycorrhiza preparation; $W L=$ soil mulched with wood chips with the addition of forest litter; $\mathrm{a}, \mathrm{ab}, \mathrm{b}, \mathrm{c}=$ data with the same letter do not differ significantly $(p<0.05)$; Others Oribatida $(N<1.0)$ : Autogneta longilamellata (Michael) in W, WL; Banksinoma lanceolata (Michael) in WL; Brachychthonius sp. Berlese in WL; Camisia biurus (C. L. Koch) in W; C. horrida (Hermann) in WL; C. segnis (Hermann) in WM; Carabodes minusculus Berlese in WL; C. subarcticus Tragardh in WL; Chamobates schuetzi (Oudemans) in WL; Eremaeus oblongus C. L. Koch in WL; Liochthonius spp. van der Hammen in W; Metabelba pulverulenta (C. L. Koch) in W, WM, WL; Oppiella neerlandica (Oudemans) in W; Oppiella nova (Oudemans) in W, WM, WL; Oribatula tibialis (Nicolet) in C, WL; Pergalumna nervosa (Berlese) in WL; Punctoribates punctum (C. L. Koch) in WL; Scheloribates laevigatus (C. L. Koch) in WL; Scheloribates latipes (C. L. Koch) in W, WL; Suctobelba spp. Paoli in W, WM, WL; Trhypochthonius tectorum (Berlese) in WL; Trichoribates trimaculatus (C. L. Koch) in W, WL. 


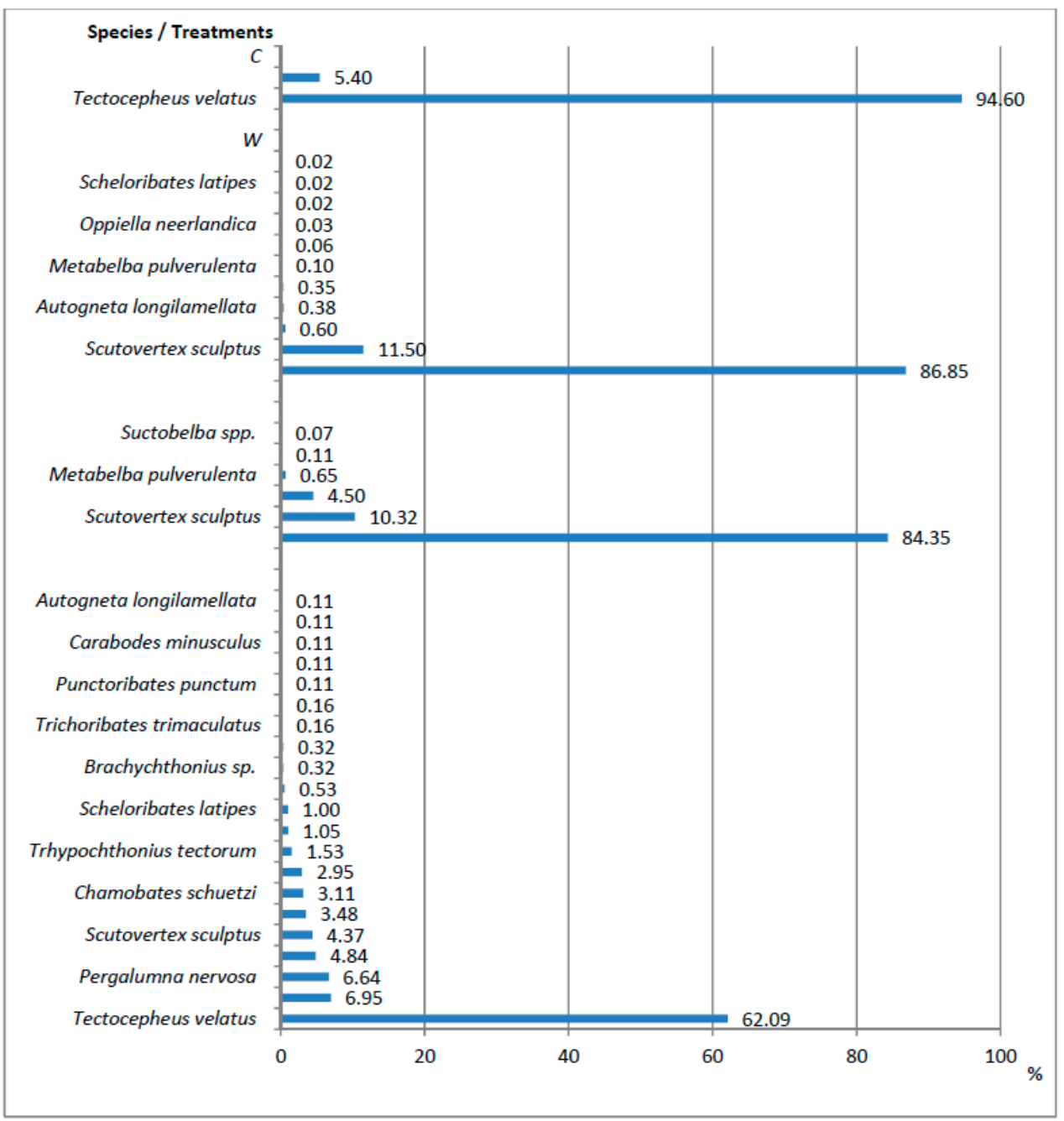

Figure 1. Domination index of the oribatid mites in the particular experiment treatments. Where: $\mathrm{C}=$ control—without mulching (Tectocepheus velatus (Michael): Tectocepheuidae; Oribatula tibialis (Nicolet): Oribatulidae); W = soil mulched with wood chips (Tectocepheus velatus (Michael): Tectocepheuidae; Scutovertex sculptus Michael: Scutoverticidae; Oppiella nova (Oudemans): Oppiidae; Autogneta longilamellata (Michael): Autognetidae; Suctobelba spp. Paoli: Suctobelbidae; Metabelba pulverulenta (C. L. Koch): Damaeidae; Camisia biurus (C. L. Koch): Camisiidae; Oppiella neerlandica (Oudemans): Oppiidae; Trichoribates trimaculatus (C. L. Koch): Ceratozetidae; Scheloribates latipes (C. L. Koch): Scheloribatidae; Liochthonius spp. van der Hammen: Brachychthoniidae); WM = soil mulched with wood chips with the addition of mycorrhiza preparation (Tectocepheus velatus (Michael): Tectocepheuidae; Scutovertex sculptus Michael: Scutoverticidae; Oppiella nova (Oudemans): Oppiidae; Metabelba pulverulenta (C. L. Koch): Damaeidae; Camisia segnis (Hermann): Camisiidae; Suctobelba spp. Paoli: Suctobelbidae); $\mathrm{WL}=$ soil mulched with wood chips with the addition of forest litter (Tectocepheus velatus (Michael): Tectocepheuidae; Oppiella nova (Oudemans): Oppiidae; Pergalumna nervosa (Berlese): Galumnidae; Eremaeus oblongus C. L. Koch: Eremaeidae; Scutovertex sculptus Michael: Scutoverticidae; Metabelba pulverulenta (C. L. Koch): Damaeidae; Chamobates schuetzi (Oudemans): Chamobatidae; Oribatula tibialis (Nicolet): Oribatulidae; Trhypochthonius tectorum (Berlese): Trhypochthoniidae; Oppiella neerlandica (Oudemans): Oppiidae; Scheloribates latipes (C. L. Koch): Scheloribatidae; Suctobelba spp. Paoli: Suctobelbidae; Brachychthonius sp. Berlese: Brachychthoniidae; Banksinoma lanceolata (Michael): Thyrisomidae; Trichoribates trimaculatus (C. L. Koch): Ceratozetidae; Scheloribates laevigatus (C. L. Koch): Scheloribatidae; Punctoribates punctum (C. L. Koch): Punctoribatidae; Carabodes subarcticus Tragardh: Carabodidae; Carabodes minusculus Berlese: Carabodidae; Camisia horrida (Hermann): Camisiidae; Autogneta longilamellata (Michael): Autognetidae). 


\section{Discussion}

\subsection{Scots Pine Growth Characteristics}

The height and width of the trunk are the two most commonly measured features that determine the size of tree biomass [30-32]. In this study, no clear effect of mulching treatments on the length of annual main stem increments of young Scots pine trees was observed. On the contrary, in a study reported by Klimek et al. [33] a significant increase in growth was noted in the case of Scots pine seedlings produced using mulching and fertilizing with compost mixed with sawdust. Compared to the control, mulching treatments used in recent studies, did not caused a significant increase in the stem base diameter of Scots pine plants in the period of the first three years after planting. In addition, mulching did not considerably affect two further features characterizing the growth of Scots pine seedling, i.e., the number and lengths of lateral shoots in the annual whorl. Compared to the results published by Klimek and Rolbiecki [32] and Klimek et al. [33], in current research, the lower growth characteristics of Scots pine plants in the first three years of cultivation on plots mulched with wood chips with the addition of forest litter can be explained by the immobilization of nutrients occurring in this treatment. According to Prescott et al. [34], accumulation of organic matter on the soil surface can affect the forest ecosystem by immobilizing nutrients, which does not allow plants to absorb them. In general, physical and environmental conditions can hinder the growth and survival rate of tree seedlings.

A different means of seedling production is also an important factor affecting plant growth after planting, as well as biomass production [30,31,33,35,36]. In studies published by Szabla [37], growth characteristics of Scots pine seedlings were observed for mycorrhized than non-mycorrhized seedlings. The author stated that the place of cultivation strongly influenced the development of seedlings. Therefore, the best growth parameters of seedling were recorded in cultivation on former agricultural land, then on forest cuttings, next on-site of a fire and in forest areas degraded by industrial emissions, and finally in areas reclaimed after sand exploitation. At the same time, the author reports that in the first three years of cultivation, the increase in height and diameter of the stem base of the mycorrhized seedlings was much larger (even by 2-3 times) than in the case of non-mycorrhized seedlings. However, in each subsequent year, the differences in height increments between mycorrhized and non-mycorrhized seedlings decreased. In this experiment, Scots pine seedlings with a covered root system produced in a container nursery were used for planting, which could somewhat reduce root mycorrhization and further slowdown the initial development of young trees.

\subsection{Acarological Research}

Mites, especially oribatid mites, are considered reliable bio-indicators of the biological condition of the soil $[6,12,13,38]$. The size of the mite population recorded on the control plots of the current experiment carried out at the post-military training ground in Bydgoszcz-Jachcice was low, but similar to the number of the mite community previously noted in the same place by Klimek and Rolbiecki [32] and Klimek et al. [33]. Both in the above research and in the current study, there was a clear numerical superiority of Actinedida over Oribatida on the control plots. In general, after mulching with wood chips, the total number of mites increased many times, and in addition Oribatida began to dominate Actinedida. The abundance ratio of two orders of mites: Oribatida and Actinedida (Or/Ac) may indicate the quality of the environment, as well as the degree of its anthropogenisation. Basically, the higher the Or/Ac value, the more stable the soil environment and the higher the level of its succession $[6,20]$. In the present study, the increase in Or/Ac values observed after using wood chips mulching on degraded soil indicates an increase in the biological balance of this habitat.

In the present study, mulching of soil with wood chips obviously raise the number as well as the species diversity of mites, especially oribatid mites. The largest increase in the oribatid mite population was observed in wood chips without additives. However, the largest rise in species diversity was recorded in wood chips with the addition of forest litter, which contains a huge amount of mesofauna 
and soil microorganisms, such as fungi and bacteria. In forest ecosystem, many micro-arthropods perform very important soil-forming functions, but one of the most important are oribatid mites. Previous studies have shown that the introduction of a 1-cm thick layer of forest litter into a suitable substrate, e.g., wood chips, is sufficient to inoculate soils with edaphon [25,33,35,36,39-41]. On the one hand, these small animals have limited adaptability to new habitats [42-44], but on the other hand, some studies show that oribatid mites appear very early in adverse habitats, even on the glacier foreland [45] or on post-industrial dumps [46]. Haimi [38] believes that the presence of mesofauna, which restores the soil biological activity, is important during soil remediation operations. Haimi [38] reported that micro-arthropods can be used in soil reclamation processes in two ways. First, micro-arthropods have a direct and indirect influence on soil metabolism, because they feed on microorganisms, which stimulates their growth and reproduction. Secondly, micro-arthropods are bio-indicators of the biological state of soils. Furthermore, oribatid mites (as vectors) have a beneficial influence on the spread of bacteria and fungi, and therefore have an indirect effect on the development of mycorrhiza $[12,17,18,47]$. The addition of fresh forest litter to reclaimed soil was successfully used already by Klimek and Rolbiecki [32,40], Klimek et al. [33], Klimek at al. [36,41], Klimek and Chachaj [25], and Klimek [39].

Among the oribatid mites, Tectocepheus velatus, for which the dominance rate ranged between $62.09 \%$ and $94.60 \%$, clearly dominated in all mulching treatments of this experiment. T. velatus is a common soil oribatid mite found in different biotopes [48]. T. velatus has a high reproduction rate and high ability to colonize new habitats. In pine forests, this species most often dominates among oribatid mites, and is also a good bio-indicator of biological activity of soil [10]. In the current study, Oppiella nova was the second (mulching with wood chips with the addition of forest litter) or the third (mulching only with wood chips and mulching with wood chips with the addition of mycorrhiza preparation) in terms of population size, oribatid mite species. Both of the above-mentioned oribatid mite species are pioneer species that produce a large number of offspring. Both Tectocepheus velatus and Oppiella nova are parthenogenic and develop according to the life strategy of type " $\mathrm{r}$ ", which means that these species have a genetically defined set of individual traits that allow them to survive $[49,50]$. In addition, these species of oribatid mites can prey on ectomycorrhiza, thus contributing to their spread [18,19]. In this study, Scutovertex sculptus also occupied an important place in the hierarchy of oribatid mites' dominance. This species clearly preferred wood chips without additions. S. sculptus is a large oribatid mite with strong sclerotization of the cuticle, and thus it is well protected against drying out and adapted to life in initial soils in conditions of strong sunlight, e.g., on fallow lands and industrial heaps $[51,52]$. In the present research, no S. sculptus was observed on control plots, however, in earlier studies carried out at the post-military training ground in Bydgoszcz-Jachcice, this species was noticed, as were Oppiella nova and Tectocepheus velatus [32]. Tectocepheus velatus, which was the most abundant oribatid mite in the control plots of current study, most likely found favorable conditions for development in wood chips and gradually inhabited them. On the control plots, Oribatula tibialis was also noted, which is classified as a eurytopic species [48,53] preferring forest soils [54], but its population did not increase due to mulching.

On plots mulched with wood chips with the forest edaphon, the oribatid mites' domination structure was more even than in the case of the other treatments used. The average number of species and the species diversity index on plots mulched with wood chips with the addition of forest litter were much higher than for other treatments. After applying this treatment, the average number of species and the species diversity index of the substrate were most similar to forest soils, which is a huge wealth of soil mesofauna $[27,28]$. The beneficial effect of adding forest litter to the mulch layer on the richness and range of identified oribatid mite species indicates the usefulness of this type of treatment in the process of the reclamation of degraded forest soils. The results confirm the good adaptation of mites in Scots pine wood chips used in the mulching process $[25,26]$. Research indicates the usefulness of Scots pine wood chips for practical use in the regeneration of degenerated soils, in which a stable forest ecosystem will be created in the future. For this purpose, wood chips can be used without 
additions, but then the succession of soil micro-arthropods can last much longer, and then the time of stable and species-diverse soil formation will likely be extended. This process can be accelerated by adding the forest soil mesoflora and mesofauna to wood chips with the litter from mature forest. When the mycorrhiza preparation was added to wood chips, no effect on the number and the species diversity of mites in the substrate was observed. The main reason for this situation may be the course of pluvial and thermal conditions during the study period; in particular, low atmospheric precipitation may have contributed to the poor development of microorganisms implanted in the substrate using a mycorrhiza preparation $[27,47]$.

\section{Conclusions}

Generally, the use of soil mulching with the Scots pine wood chips did not affect the growth characteristics of young Scots pine plants, but significantly improved the abundance and species diversity of mites in the substrate. Mulching treatments increased the number and species diversity of mites, especially oribatid mites, which began to dominate among micro-arthropods. The number of oribatid mites increased the most after mulching with wood chips without additives, which creates a good environment for the development of mites, but has a poor edaphon; therefore, the species diversity was low there. In contrast, mulching with wood chips with the addition of forest litter, which is a rich and natural source of mesofauna, contributed to the largest increase in the diversity of mite species. Among oribatid mites, Tectocepheus velatus, Oppiella nova and Scutovertex sculptus, which are known for their high ability to colonize new habitats, clearly dominated in all mulching treatments. In sum, research has shown that mulching with Scots pine wood chips, particularly with the addition of forest litter, considerably enriches soil fauna, thus contributing to the regeneration process of degenerated forest soils.

Author Contributions: Conceptualization, A.K., S.R., R.R. and P.S.; methodology, A.K. and P.S.; software, A.K., P.S.; validation, A.K., S.R. and R.R.; formal analysis, A.K., S.R., R.R. and G.G.; investigation, A.K., S.R., R.R. and G.G.; resources, A.K. and G.G.; data curation, A.K. and P.S.; writing-original draft preparation, A.K., P.S. and B.J.; writing-review and editing, A.K., S.R., R.R. and B.J.; visualization, A.K., S.R., R.R., G.G. and B.J.; supervision, A.K., S.R., R.R., P.S. and B.J.; project administration, A.K. and P.S.; funding acquisition, A.K., S.R. and R.R. All authors have read and agreed to the published version of the manuscript.

Funding: This research received no external funding.

Acknowledgments: The authors would like to thank the employees of the Żołedowo Forest District for enabling research and valuable help during the experiment.

Conflicts of Interest: The authors declare no conflict of interest.

Note: Andrzej Klimek the first author of this paper died on 10 June 2020. Our colleague died while preparing this publication for printing. Scientific cooperation with Andrzej was an honor for us. Andrzej will always remain in our memory.

\section{References}

1. CSO. Statistical Information and Elaborations: Environment; Central Statistical Office Regional and Environmental Surveys Department: Warszawa, Poland, 2017; p. 122.

2. Koreleski, K. Ecological, legal and planning problems of afforestation in the rural areas. Inż. Roln. 2003, 3, 251-260.

3. Milewski, W. Lasy w Polsce [Forests in Poland]; CILP: Warszawa, Poland, 2017.

4. Nakicenovic, N. Emissions Scenarios. In The Intergovernmental Panel on Climate Change (IPCC) Special Report on Emissions Scenarios; Cambridge University Press: Cambridge, UK, 2000.

5. Lindberg, N.; Bengtsson, J. Population responses of oribatid mites and collembolans after drought. Appl. Soil. Ecol. 2005, 28, 163-174. [CrossRef]

6. Gulvik, M.E. Mites (Acari) as indicators of soil biodiversity and land use monitoring: A review. Pol. J. Ecol. 2007, 55, 415-440. 
7. Brzezińska, M. Aktywność biologiczna oraz procesy jej towarzyszące w glebach organicznych nawadnianych oczyszczonymi ściekami miejskimi (badania polowe i modelowe) [Biological activity and associated processes in organic soils irrigated with treated municipal wastewater (field and model studies)]. Acta Agrophys. 2006, 131, 164.

8. Olszowska, G.; Zwoliński, J.; Matuszczyk, I.; Syrek, D.; Zwolińska, B.; Pawlak, U.; Kwapis, Z.; Dudzińska, M. Wykorzystanie badań aktywności biologicznej do wyznaczenia wskaźnika żyzności gleb w drzewostanach sosnowych na siedliskach boru świeżego i boru mieszanego świeżego [The use of biological activity for testing the soil fertility index in pine stands on fresh and fresh mixed forest habitats]. Leśne Prace Badawcze 2005, 3, 17-37.

9. Axelsson, B.; Lohm, U.; Lundkvist, H.; Persson, T.; Sköglund, J.; Wiren, A. Effects of nitrogen fertilization on the abundance of soil fauna populations in a Scots pine stand. Res. Notes R. Coll. For. 1973, 14, 5-10.

10. Seniczak, S.; Bukowski, G.; Seniczak, A. Mechowce (Acari, Oribatida) glebowe strefy ekotonowej pomiedzy borem sosnowym a brzegiem Jeziora Lobeliowego Wielkie Gacno w Borach Tucholskich [Oribatid mites (Acari, Oribatida) of ecotone between scots pine forest and Lobelias Lake Wielkie Gacno in Tuchola Forest]. Zesz. Nauk. Zootechnika 2006, 248, 39-44.

11. Ruf, A.; Beck, L. The use of predatory soil mites in ecological soil classification and assessment concepts, with perspectives for oribatid mites. Ecotox. Environ. Safe. 2005, 62, 290-299. [CrossRef]

12. Behan-Pelletier, V.M. Oribatid mite biodiversity in agroecosystems: Role of bioindication. Agric. Ecosyst. Environ. 1999, 74, 411-423. [CrossRef]

13. Behan-Pelletier, V.M. Acari and Collembola biodiversity in Canadian agricultural soils. Can. J. Soil Sci. 2003, 83, 279-288. [CrossRef]

14. Luxton, M. Studies on the oribatid mites of a Danish beech wood soil. I. Nutritional biology. Pedobiologia 1972, 12, 434-463.

15. Ponge, I.F. Succession of fungi and fauna during decomposition of needles in a small area of Scots pine litter. Plant. Soil 1991, 138, 99-113. [CrossRef]

16. Renker, C.; Otto, P.; Schneider, K.; Zimdars, B.; Maraun, M.; Buscot, F. Oribatid Mites as Potential Vectors for Soil Microfungi: Study of Mite-Associated Fungal Species. Microb. Ecol. 2005, 50, 518-528. [CrossRef] [PubMed]

17. Schneider, K.; Renker, C.; Maraun, M. Oribatid mite (Acari, Oribatida) feeding on ectomycorrhizal fungi. Mycorrhiza 2005, 16, 67-72. [CrossRef]

18. Remén, C.; Fransson, P.; Persson, T. Population responses of oribatids and enchytraeids to ectomycorrhizal and saprotrophic fungi in plantesoil microcosms. Soil Biol. Biochem. 2010, 42, 978-985. [CrossRef]

19. Schneider, K.; Renker, C.; Scheu, S.; Maraun, M. Feeding biology of oribatid mites: A minireview. Phytophaga 2004, XIV, 247-256.

20. Werner, M.R.; Dindal, D.L. Effects of conversion to organic practices agricultural on soil biota. Am. J. Alternative Agr. 1990, 5, 24-32. [CrossRef]

21. Hilszczańska, D. Mycorrhizal development and growth of inoculated Scot pine seedlings in different soil moisture conditions in the glasshouse. Sylwan 2001, 7, 89.

22. Kropp, B.R.; Langloi, S.G.C. Ectomycorrhiza in reforestation. Can. J. For. Res. 1990, 20, 438. [CrossRef]

23. Marx, D.H. Ectomycorrhizal fungus inoculation: A tool for improving forestation practices. In Tropical Mycorrhiza Research; Mikola, P., Ed.; Oxford University Press: New York, NY, USA, 1980; pp. 13-71.

24. Molina, R.; Trappe, J.P. Mycorrhiza management in bare-root nurseries. In Forest Nursery Manual Production of Bareroot Seedlings; Duryea, M., Landis, T.D., Eds.; Nijhoff/Junk: The Hague, The Netherlands, 1984; pp. 211-223.

25. Klimek, A.; Chachaj, B. Comparison of seasonal dynamics of mite (Acari) aggregation in pine forest litter and pine chips. Infrastruct. Ecol. Rural Areas 2015, 2, 405-417.

26. Klimek, A.; Chachaj, B. Colonization of hardwood and pine wood chips by mites (Acari), with particular reference to oribatid mites (Oribatida). Folia For. Pol. Ser. A For. 2018, 60, 22-33. [CrossRef]

27. Klimek, A.; Chachaj, B.; Gackowski, G. The presence of mites (Acari) in pine wood chips enriched with peat and lignite inoculated with forest litter and irrigated. Infrastruct. Ecol. Rural Areas 2017, II/1, 483-493.

28. Klimek, A.; Chachaj, B.; Gackowski, G.; Kosakowski, L. Mite (Acari) colonization of pine chips alone and pine chips supplemented with forest litter, peat and lignite in revitalization of degraded forest soils. Infrastruct. Ecol. Rural Areas 2017, IV/2, 1577-1590. 
29. Berthet, P.; Gerard, G. A statistical study of microdistribution of Oribatei (Acari) I. The distribution pattern. Oikos 1965, 16, 214-227. [CrossRef]

30. Orzeł, S. Biomasa sadzonek sosny zwyczajnej w uprawie doświadczalnej na rekultywowanym wyrobisku piasku i w terenie silnie skażonym imisjami przemysłowymi [Biomass of Scots pine seedlings in experimental cultivation on reclaimed sand pits and in areas heavily contaminated with industrial immissions]. In Ektomikoryzy. Nowe biotechnologie w polskim szkótkarstwie leśnym [Ectomycorrhiza. New biotechnologies in Polish forestry nursery]; Kowalski, S., Ed.; CILP: Warszawa, Poland, 2007; pp. 336-358.

31. Klimek, A.; Rolbiecki, S.; Rolbiecki, R.; Malczyk, P. Impact of chosen bare root nursery practices on white birch seedling quality and soil mites (Acari). Pol. J. Environ. Stud. 2009, 18, 1013-1020.

32. Klimek, A.; Rolbiecki, S. Growth of Scots pine (Pinus sylvestris L.) and occurrence of soil mites (Acari) on the reclaimed post-military area at forest district Żołędowo. Infrastruct. Ecol. Rural Areas 2011, 1, 249-262.

33. Klimek, A.; Rolbiecki, S.; Rolbiecki, R.; Hilszczańska, D.; Malczyk, P. Impact of chosen bare root nursery practices in Scots pine seedling quality and soil mites (Acari). Pol. J. Environ. Stud. 2008, 17, 247-255.

34. Prescott, C.E.; Maynard, D.G.; Laiho, R. Humus in northern forests: Friend or foe? For. Ecol. Manag. 2000, 133, 23-36. [CrossRef]

35. Klimek, A.; Rolbiecki, S.; Rolbiecki, R.; Hilszczańska, D.; Malczyk, P. Effects of organic fertilization and mulching under micro-sprinkler irrigation on growth and mycorrhizal colonization of European larch seedlings, and occurrence of soil mites. Pol. J. Environ. Stud. 2011, 5, 1211-1219.

36. Klimek, A.; Rolbiecki, S.; Rolbiecki, R.; Długosz, J.; Musiał, M. The use of compost from sewage sludge and forest ectohumus for enrichment of soils in the nursery cultivation of littleleaf linden (Tilia cordata Mill.). Annu. Set Environ. Prot. 2013, 15, 2811-2828.

37. Szabla, K. Cechy morfologiczno-rozwojowe oraz przeżywalność sadzonek różnych gatunków drzew leśnych w uprawach doświadczalnych na gruntach nieleśnych i leśnych o różnym stopniu degradacji [Morphological and developmental features and survival of seedlings of various forest tree species in experimental crops on non-forest and forest land with varying degrees of degradation]. In Ektomikoryzy. Nowe biotechnologie w polskim szkótkarstwie leśnym [Ectomycorrhiza. New biotechnologies in Polish forestry nursery]; Kowalski, S., Ed.; CILP: Warszawa, Poland, 2007; pp. 289-336.

38. Haimi, J. Decomposer animals and bioremediation of soils. Environ. Pollut. 2000, 107, 233-238. [CrossRef]

39. Klimek, A. Possibility of use of ectohumus for revitalization of soils in forest nurseries. Manag. Environ. Prot. Forests 2010, 4, 80-93.

40. Klimek, A.; Rolbiecki, S. Moss mites (Acari: Oribatida) in soil revitalizing: A chance for practical application in silviculture. Biol. Lett. 2014, 51, 71-82. [CrossRef]

41. Klimek, A.; Rolbiecki, S.; Rolbiecki, R.; Hilszczańska, D.; Malczyk, P. The effect of nursery measures on mycorrhizal colonisation of Scots pine and occurrence of soil mites. Sci. Res. Essays. 2012, 7, 2380-2389.

42. Beckmann, M. Die Entwicklung der Bodenmesofauna eines Ruderal Ökosystems und ihre Beeinflussung durch Rekultivierung: 1. Oribatiden. Pedobiologia 1988, 31, 391-408.

43. Wanner, M.; Dunger, W. Primary immigration and succession of soil organisms on reclaimed opencast coal mining areas in eastern Germany. Eur. J. Soil Biol. 2002, 38, 137-143. [CrossRef]

44. Lehmitz, R.; Russell, D.; Hohberg, K.; Christian, A.; Xylander, W.E.R. Wind dispersal of oribatid mites as a mode of migration. Pedobiologia 2011, 54, 201-207. [CrossRef]

45. Gwiazdowicz, D.; Zawieja, B.; Olejniczak, I.; Coulson, S.J. Changing Microarthropod Communities in Front of a Receding Glacier in the High Arctic. Insects 2020, 11, 226. [CrossRef]

46. Dunger, W. The return of soil fauna to coal mined areas in the German Democratic Republic. In Animals Primary Succession: The Role of Fauna in Reclaimed Lands; Mayer, D.J., Ed.; Cambridge University Press: Cambridge, UK, 1989; pp. 307-337.

47. Klironomos, J.N.; Kendrick, W.B. Palatability of microfungi to soil arthropods in relation to the functioning of arbuscular mycorrhizae. Biol. Fertil. Soils 1996, 21, 43-52. [CrossRef]

48. Weigmann, G.; Kratz, W. Die deutschen Hornmilbenarten und ihre ökologische Charakteristik. Zool. Beitr. 1981, 27, 459-489.

49. Siepel, H. Life-history tactics of soil microarthropods. Biol. Fertil. Soils 1994, 18, 263-278. [CrossRef]

50. Skubała, P.; Gulvik, M. Pioneer oribatid mite communities (Acari: Oribatida) in natural (glacier foreland) and anthropogenic (post-industrial dumps) habitats. Pol J. Ecol 2005, 53, 105-111. 
51. Skubała, P. Colonization of a dolomitic dump by oribatid mites (Acari, Oribatida). Pedobiologia 1999, 43, 145-159.

52. Rolbiecki, S.; Stypczyńska, Z.; Klimek, A.; Długosz, J.; Rolbiecki, R. Flora and some properties of fallow soil which was previously under arable cultivation in conditions of sprinkler irrigation. Infrastruct. Ecol. Rural Areas 2006, 2/1, 183-194.

53. Weigmann, G. Oribatid communities in transects from bogs to forests in Berlin indicating the bio-tope qualities. In Proceedings of 8th International Congress on Acarology. Modern Acarology; Dusbanek, F., Bukva, V., Eds.; Academia, Prague and SPB Academic Publishing: The Hague, The Netherlands, 1991; pp. 359-364.

54. Rajski, A. Autecological-zoogeographical analy-sis of moss mites (Acari, Oribatei) on the basis of fauna in the Poznań environs. Part II. Fragm. Faun. 1968, 12, 277-405.

(C) 2020 by the authors. Licensee MDPI, Basel, Switzerland. This article is an open access article distributed under the terms and conditions of the Creative Commons Attribution (CC BY) license (http://creativecommons.org/licenses/by/4.0/). 